\title{
Tracking Short-Range Attraction and Oviposition of European Grapevine Moths Affected by Volatile Organic Compounds in a Four-Chamber Olfactometer
}

\author{
Anna Markheiser ${ }^{1, *} \mathbb{\infty}$, Margit Rid ${ }^{2}$, Sandra Biancu ${ }^{1}$, Jürgen Gross ${ }^{2,3}$ 이 and \\ Christoph Hoffmann ${ }^{1}$ \\ 1 Institute for Plant Protection in Fruit Crops and Viticulture-Zoology and Integrated Plant Protection, \\ Julius Kühn-Institut (JKI), Federal Research Centre for Cultivated Plants, Geilweilerhof, 76833 Siebeldingen, \\ Germany; sandra.biancu@julius-kuehn.de (S.B.); christoph.hoffmann@julius-kuehn.de (C.H.) \\ 2 Institute for Plant Protection in Fruit Crops and Viticulture-Applied Chemical Ecology, Julius \\ Kühn-Institut (JKI), Federal Research Centre for Cultivated Plants, Schwabenheimer Str. 101, 69221 \\ Dossenheim, Germany; margit.rid@julius-kuehn.de (M.R.); juergen.gross@julius-kuehn.de (J.G.) \\ 3 Plant Chemical Ecology, Technical University of Darmstadt, Schnittspahnstr. 4, 64287 Darmstadt, Germany \\ * Correspondence: anna.markheiser@julius-kuehn.de
}

Received: 13 December 2019; Accepted: 6 January 2020; Published: 8 January 2020

\begin{abstract}
The identification of volatile organic compounds (VOCs) leading to short-range attraction and oviposition of the European grapevine moth Lobesia botrana and European grape berry moth Eupoecilia ambiguella (Lepidoptera: Tortricidae) is crucial in order to establish bait-based decision support systems for control of these pests. Therefore, we developed a method to measure the real-time behavioral response of female moths to VOCs using a four-chamber olfactometer coupled with a video tracking system. Ten synthetic VOCs were selected for this study: (S)-(-)-perillaldehyde, $(E) /(Z)$-linalool oxide, $( \pm)$-limonene, linalool, $(E)-\beta$-caryophyllene, $\alpha / \beta$-farnesene, $(-)$ - $\alpha$-cedrene, methyl salicylate and cumene. The effect of VOCs on egg deposition was determined using a dual-choice oviposition test, whereas perception by female antennae was verified using electroantennography (EAG). During video tracking, females responded to volatile compounds emitted by grapevine with higher antennae and ovipositor activity than to air control. $(E) /(Z)$-linalool oxide, cumene and (S)-(-)-perillaldehyde released ovipositor activity of L. botrana, while the latter provoked oviposition. $(R) /(S)$-limonene affected ovipositor activity of E. ambiguella, whereas none of the VOCs tested attracted for oviposition. The results suggest that females have the ability to perceive specific VOCs by the antennae but also by the ovipositor, which could attract or repel for egg deposition.
\end{abstract}

Keywords: L. botrana; E. ambiguella; grape berry moth; VOC; host plant choice; behavior; egg deposition; EAG; kairomones; pheromones

\section{Introduction}

The selection of actual host plants by herbivorous insects for reproduction is amongst others triggered by the emitted host plant bouquet, specified as volatile organic compounds (VOCs). In this regard, Lepidoptera belong to a well-studied order of insects [1], in which the European grapevine moth L. botrana and the European grape berry moth E. ambiguella are also included. They are two of the most important insect pests threatening European viticulture [2], whereas L. botrana has been reported as a new grape pest in the Americas: California, Chile and Argentina [3-5]. Both species are crepuscular [6,7] and mainly oviposit on the surface of fructiferous organs of plants, whereas several families were identified as hosts (e.g., Vitaceae, Oleaceae, Thymeleaceae and Rosaceae) [8-12]. Most 
notably, they are multivoltine on grapevine. L. botrana is able to complete up to four generations per year under favorable climatic conditions [13]. The first generation is considered to be exclusively anthophagous (flower-feeding) and may cause direct yield losses to a greater extent than the following carpophagous (fruit-feeding) generations $[14,15]$. Direct damage is caused by feeding of larvae on immature, ripening and ripe berries, which indirectly promotes an infection by the grey mold fungus Botrytis cinerea Persoon: Fries [16,17]. In certain cases, the direct damage favors the colonization of acetic acid bacteria and yeasts, which may cause greater incidence of sour rot in presence of Drosophila spp. [18,19].

Several studies have investigated the oriented flight of females and males to host plants [20-24], whereas less evidence has been given on short-range attraction. Especially for females, VOCs are assumed to initiate the crucial step of oviposition $[25,26]$, which finally triggers pest infestation in vineyards. It has already been proven that L. botrana females have sensory structures, which allow the contact detection of physical and chemical stimuli that show no or reduced volatility after settlement on a plant $[26,27]$. Mainly non-porous sensilla and terminal pore sensilla, located at the legs, the ovipositor, the proboscis and the antennal tip of females are assumed to evaluate particular plants as hosts [27]. In former studies, the behavioral effect of single compounds identified in the scent bouquet of grapevine was evaluated by the flight activity of females in wind tunnel studies [28-30]. The perception of VOCs by female's antennae was measured using electroantennography (EAG) $[20,24]$, while a comparable method to evaluate the influence of VOCs on short-range attraction and oviposition activity is still missing. In particular, receptors on the ventral surface of the ovipositor are assumed to allow the detection of plant allelochemicals and/or deterrents [27,31].

Therefore, we developed a method to measure essential behavioral patterns, which reflect female's orientation to suitable egg laying sites. The aim was to (i) quantify female short-range attraction induced by VOCs and (ii) determine the effect of volatiles on oviposition behavior. The general perceptibility of single VOCs by E. ambiguella and L. botrana female antennae was verified using EAG. To assess short-range orientation to host plants and VOCs, a four-chamber olfactometer assay was developed, which allows female behavior to be tracked, like settlement near volatile sources, flight activity and movement of the antennae or ovipositor. Especially the observation of ovipositor movement can be used as evidence for compounds, which are recognized by the ovipositor's sensilla.

Furthermore, the results contribute to the identification of VOCs, which are responsible for females' oviposition decisions. They can be used for the development of bait-based tools for the control of these pests.

\section{Materials and Methods}

\subsection{Insect Rearing}

Moths used in the bioassays were taken from an insect culture established at Julius Kühn-Institut, Siebeldingen, Germany. They were reared according to Markheiser et al. [32] on a semi-artificial diet. Pupae were separated by sex [12], individually transferred into $15 \mathrm{~mL}$ falcon tubes (VWR International $\mathrm{GmbH}$, Darmstadt, Germany) and closed using a moisturized cellulose-plug. One male and one female moth (age $<24 \mathrm{~h}$ ) were coupled $48 \mathrm{~h}$ before the bioassay was carried out. One hour before starting the experiments, at the beginning of dusk, couples were separated and females, which deposited $>10$ eggs during copulation period, were used for the study. The insect rearing was conducted under controlled climatic conditions of $14: 8 \mathrm{~h}$ (light:dark) photoperiod, $1 \mathrm{~h}$ each of dusk and dawn, $23: 19 \pm 2{ }^{\circ} \mathrm{C}$ and $70 \pm 5 \%$ relative humidity. The species L. botrana and E. ambiguella were kept separated from each other in climatic chambers 'Fitotron type SGR233' (Weiss Technik UK Ltd., Loughborough, UK). The day-night setback within the chambers was shifted by $8 \mathrm{~h}$ in advance to ensure higher oviposition activity during the studies, which preferably appears during dusk as observed by Stellwaag [7]. 


\subsection{Volatile Organic Compounds (VOCs)}

Potted grapevine plants, cv. 'Regent', were used for the validation of the behavioral studies. They were propagated by wood cuttings and cultured in a greenhouse at Julius Kühn-Institut, Siebeldingen, Germany, under controlled conditions of $23 \pm 5{ }^{\circ} \mathrm{C}$ and $30 \pm 10 \%$ relative humidity. A fungicide treatment against powdery mildew (Erysiphe necator) was conducted once a week with either Vivando (500 g/L metrafenone, BASF SE, Ludwigshafen, Germany), Talendo (200 g/L propynazide, DuPont, Wilmington, DE, USA) or Dynali ( $60 \mathrm{~g} / \mathrm{L}$ difenoconazole $+30 \mathrm{~g} / \mathrm{L}$ cyflufenamide, Syngenta, Basel, Swizerland). No insecticides were applied. Fourteen days before the start of the experiment, fungicide treatments were stopped.

Synthetic VOCs examined in this study (Appendix A) were selected from literature [28-30,33,34]. All volatiles were identified as components of the scent of the host plants grapevine (Vitis vinifera) or flax-leaved daphne (Daphne gnidium). Except from the components mentioned in Rid et al. [34] and Cattaneo [35], VOC blends differ in their chemical composition and induce an attraction of L. botrana or E. ambiguella females in wind tunnel studies. The following ten substances were tested individually: $(S)-(-)$-perillaldehyde, $(E) /(Z)$-linalool oxide (furanoid), (E)/(Z)-linalool oxide (pyranoid), ( \pm )-limonene, linalool, (E)- $\beta$-caryophyllene, $\alpha / \beta$-farnesene (mixture of isomers), $(-)-\alpha$-cedrene, methyl salicylate and cumene. All chemical substances except $(E) /(Z)$-linalool oxide (pyranoid) (Nippon Terpene Chemicals Inc., Kōbe, Japan) were purchased from Merck, Darmstadt, Germany.

\subsection{Electroantennography (EAG)}

The response of mated females' antennae of L. botrana and E. ambiguella to volatiles was studied using EAG. Moths' antennae were excised with fine scissors. The reference electrode of the EAG device was connected to the base of the antenna, whereas the recording electrode was connected to the tip of the antenna, while the last segment of antenna was cut off. Glass capillaries $(0.58 \mathrm{~mm}$ I.D., Science Products, Hofheim, Germany) filled with Ringer solution ( $\mathrm{NaCl} 7.5 \mathrm{~g}, \mathrm{KCl} 0.35 \mathrm{~g} \mathrm{CaCl}_{2}$ $0.21 \mathrm{~g}$ ad $1 \mathrm{~L} \mathrm{H}_{2} \mathrm{O}$ ) were used as electrodes and connected to silver wire. The analogue signal was detected with a probe (INR-II, Ockenfels Syntech ${ }^{\circledR}$, Kirchzarten, Germany), captured and processed with a data acquisition controller (IDAC-2, Ockenfels Syntech ${ }^{\circledR}$ ) and analyzed with EAG software (EAGpro, Ockenfels Syntech ${ }^{\circledR}$ ). The air passing over the antenna was filtered using activated charcoal and humidified. To prepare the odor sources, a piece of filter paper (type 413, VWR International bvba, Belgium) was placed into the wide end of standard glass Pasteur pipettes. One $\mu \mathrm{L}$ of each test substance was pipetted onto the filter paper. The odor-loaded pipette was immediately placed in-line with the puff apparatus. For stimulation, an air puff $(1 \mathrm{~s}$, flow $=1.4 \mathrm{~L} / \mathrm{min})$ was passed through the pipette transporting the respective VOC to the continuous airflow $(1.5 \mathrm{~L} / \mathrm{min})$ that passed over the antenna. The order of a set of puffs was as following: control (only filter paper), solvent control (only dichloromethane (DCM), Merck, Darmstadt, Germany), test substance (diluted in DCM), control, solvent control, and reference substance (diluted in DCM). This set was repeated three times per antenna while the substances were pipetted on a fresh filter paper for each set immediately before use. A refractory phase of $5 \mathrm{~s}$ was kept between the single puffs.

Response of the antenna was confirmed by controlling with a reference substance (E. ambiguella: linalool $(10 \mu \mathrm{g} / \mu \mathrm{L})$, L. botrana: $\alpha / \beta$-farnesene (mixture of isomers, $10 \mu \mathrm{g} / \mu \mathrm{L})$ ). The test substances were puffed onto the antenna, and differences of the sum of the receptor potentials from individual olfactory receptor neurons $[\mathrm{mV}]$ were analyzed. Amplitudes statistically significantly higher than amplitudes derived from solvent control (DCM puff, eliciting mechanoreceptors and others) represent perceivable substances.

\subsection{Four-Chamber Olfactometer Assays}

The influence of volatiles on the behavior of mated L. botrana and E. ambiguella females was proven in a four-chamber olfactometer system (CADS-4CCP, Sigma Scientific LLC, Micanopy, FL, 
USA). It consisted of a five-port system $(30 \times 30 \times 2.5 \mathrm{~cm})$ with a removable lid out of glass $(0.6 \mathrm{~cm}$ thickness) and wing nuts for air-tight sealing. The main body and the inlet and outlet ports were made from solid ultra-high-molecular-weight polyethylene (UHMW-PE).

The arena, where the insects remain during inspection, was shaped like a four-pointed star (Figure 1). Each point of the star was connected to an inlet port, which enabled the insertion of either an external volatile source (plant headspace or synthetic volatile) or a reference source (clean air or solvent). Each inlet was connected to a set of borosilicate glass elements and consisted of an insect isolation trap (IIT) and a Teflon-tube adapter. The volatiles were provided via an inline odor source adaptor (IOA), which was connected to the IIT. The IIT collected insects responding to an odor source and prevented them from returning into the arena or reaching the odor source. Moths were separately introduced into the olfactometer arena via a fifth port, a bottom fed insect inlet adapter (IIA) made of borosilicate glass and equipped with a glass frit, to stop them from moving into the connected vacuum system.

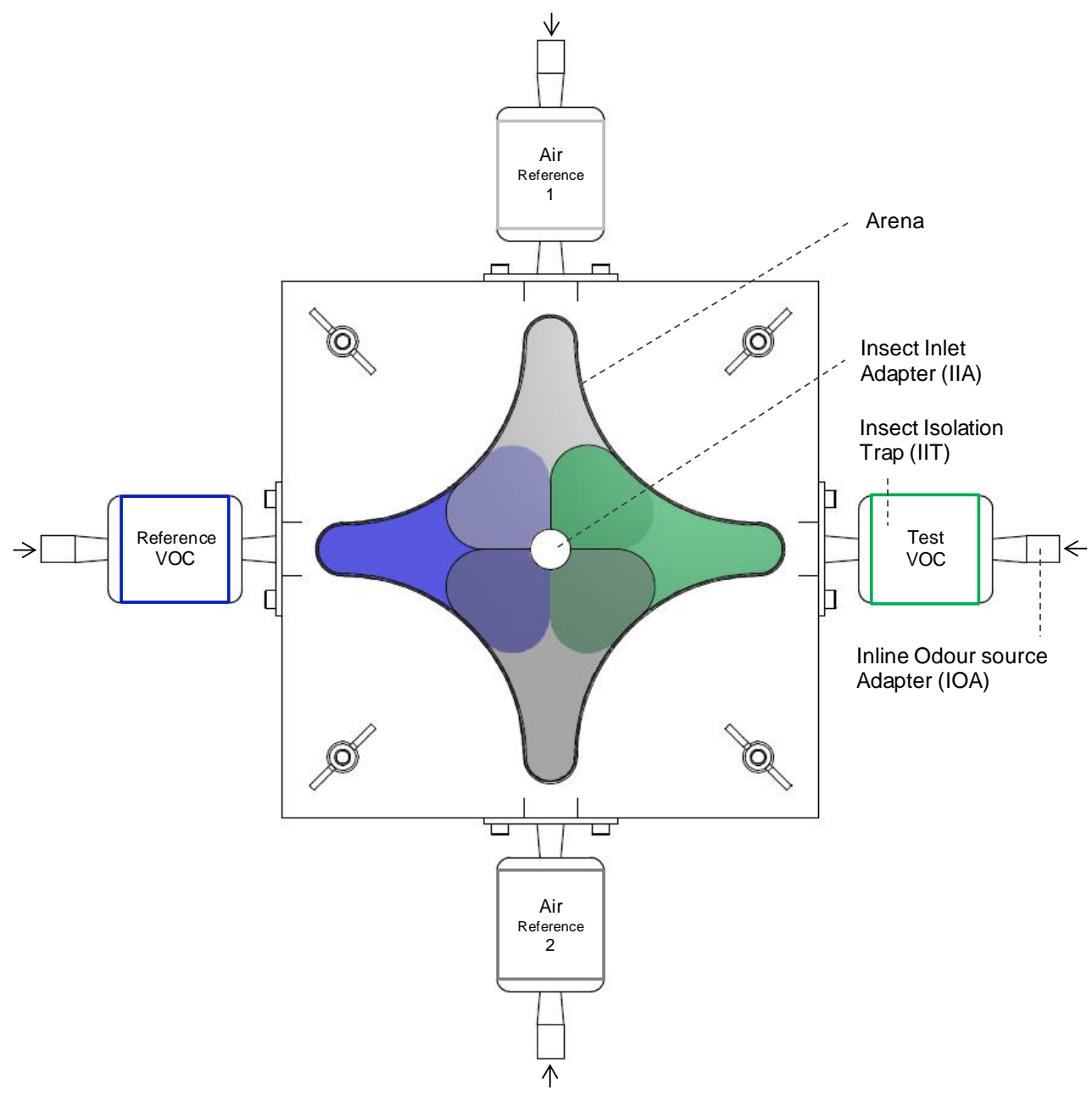

Figure 1. Top view of the four-chamber olfactometer. Insect arena is divided in four overlapping volatile organic compound (VOC) sectors, marked by colors. Arrows mark the connection to the clean air delivery system (CADS).

To operate the system, a four push with one pull clean air delivery system (CADS, Sigma Scientific LLC, Micanopy, FL, USA) was connected via Teflon-tubes (OD: $0.635 \mathrm{~cm}$, ID: $0.396 \mathrm{~cm}$ ) to the ports of the arena. The CADS was coupled to a compressed air source of 1.5 bar pressure. Four output (push) flowmeters controlled the flow of clean air into each port of the system and the vacuum (pull) side was connected to the IIA. 
The flowmeters of the CADS were adjusted to values, which enable a uniform spread of the volatiles within the olfactometer arena. To prevent a high or low atmospheric pressure within the system, the vacuum must be equal to the sum of the four single air pressures $(p v a c=p 1+p 2+p 3$ + p4). Smoke-pens (Björnax AB, Nora, Sweden), placed inside the IITs, were used to visualize the dispersal of volatiles within the system under different airflow adjustments. The arena was divided into four identical odor sectors (color markings in Figure 1). For each pressure source at the CADS, a value of 0.2 mbar was adjusted to provide a laminar flow within the arena and hence used for the choice experiments (and 0.8 mbar for the vacuum source).

To validate the attraction of moths within the four-chamber olfactometer in general, males known to be attracted by species-specific pheromones were introduced into the system. The IIT was equipped with a pheromone source of a delta-trap (Bio-Pherotrap, Temmen GmbH, Hattersheim, Germany), specific for alluring males of L. botrana ((E,Z)-7,9-dodecadienyl acetate) and E. ambiguella ((Z)-9-dodecenyl acetate). The pheromone source was unpacked and stored in a fume cupboard $98 \mathrm{~h}$ before the beginning of the experiments to reduce high concentration levels within the system.

In contrast to males, the behavior of females within the system was evaluated by providing grapevine headspace. A visual healthy grapevine cluster (plant reduced to one grape cluster and four leaves $24 \mathrm{~h}$ before the experiment) was wrapped in an oven plastic bag (Toppits ${ }^{\circledR}$, Cofresco Frischhalteprodukte GmbH \& Co. KG, Minden, Germany) according to [34,36]. Cut surfaces were sealed with Parafilm ${ }^{\circledR}$ to prevent an evaporation of green leaf volatiles produced by injuries. Two Teflon-tubes were, via a $50 \mathrm{~mL}$ Falcon tube, airproof fixed at the oven bag. One was connected to the CADS to pass air into the system and the other was connected to one port of the olfactometer system (IOA) to enable overpressure to pass off. Synthetic volatiles were provided to the females in volumes of $5 \mu \mathrm{L}$ (1:100 dilutions in DCM; Alfa Aesar, Karlsruhe, Germany), presented on filter paper $(10 \times 10 \mathrm{~mm}$, Schleicher \& Schuell, Dassel, Germany) and inserted in the IOA. Twenty-five moths (age $<72 \mathrm{~h}$ ) were observed per volatile source over a period of five minutes each.

Females and males were evaluated in different experimental approaches. After each trial (moth), the IOA, the arena and the glass lid of the arena were rinsed with $70 \%$ ethanol and the chemical component was renewed. At the end of the experiment, all glass elements and Teflon-tubes were cleaned with $70 \%$ ethanol and baked out at $130{ }^{\circ} \mathrm{C}$ for at least $12 \mathrm{~h}$. The UHMW-PE components (arena system and IOA connecting elements) were rinsed with $70 \%$ ethanol.

\subsection{Video Tracking System}

For a uniform recording of the female's position within the olfactometer arena, a digital camera (Basler GenICam acA1300-30um, Basler AG, Ahrensburg, Germany) was installed $1 \mathrm{~m}$ above the center of the arena and coupled with an EthoVision ${ }^{\circledR} \mathrm{XT}$ (version 10) video tracking software (Noldus Information Technology, Wageningen, The Netherlands).

The software tracks the moth (an automatic detection) within a specific sector of the arena. Four volatile sectors were generated within the software system based on the previously observed distribution of the smoke within the arena (Figure 1). The following detection settings were adjusted: method: static subtraction; video sample rate: 25,000/s (video pixel smoothing: none; track noise reduction: off); subject is: darker (than background); dark contrast: 0-200 px; subject size: 0-750 px; subject contour: erode first, than dilate (4 px (erosion); $3 \mathrm{px}$ (dilation)). During the tracking mode of static subtraction, the software calculates differences between a life image (recorded with moth) and a reference image (recorded prior to the introduction of the moth into the olfactometer system). As the tracking mode needs uniform and indirect illumination during the whole experiment, four dimmable LED lamps (Purelite 4 in 1 Crafters Magnifying lamp, Groves, Aylesbury, UK) were installed at the corners of the arena. Given that female moths are crepuscular, low intensities of illumination were necessary during the behavioral experiments. In our setup we observed $90 \mathrm{~lx}$ as the lowest level at which moths could be grabbed by the software system. The illumination intensity at the four exits 
(entry to IIT) of the arena was measured with a portable luxmeter (model 93560D, Beha Amprobe, Glottertal, Germany) and adjusted to $90 \pm 21 x$, whereas the room temperature was set at $21 \pm 2{ }^{\circ} \mathrm{C}$.

Based on the predefined trial control settings, the tracking mode was initiated automatically as soon as the moth entered one of the four volatile sectors and stopped after five minutes. Confirmed by the observed distribution of the smoke within the system, a longer period resulted in a spread of the VOC to further volatile sectors. Females were discarded if more than three minutes passed until they entered the arena. The duration (in seconds) spent in each volatile sector was calculated. Conspicuous behavior of the moth during the experiment was, after a visual registration by the operator, manually recorded by the aid of a wireless touchpad keyboard (model E2700, Rapoo Europe BV, Bergschenhoek, The Netherlands). The record of the behavior was switched on/off via a predefined button ("a" = antennae activity, " $\mathrm{f}$ " = flight activity and "o" = ovipositor activity) on the keyboard. The software subsequently assigned the behavior to a specific volatile sector and its duration (in seconds) and frequency for each sector was calculated.

\subsection{Oviposition Bioassay}

The effect of VOCs on oviposition was quantified using a dual choice oviposition assay in comparison to a solvent (DCM). The volatiles were offered via a dispenser system, a $2 \mathrm{~mL}$ Eppendorf vial filled to one third with an unscented cotton wick (Ebelin, dm-Drogerie Markt GmbH $+\mathrm{Co}$. KG, Karlsruhe, Germany). The cotton wick was loaded with the test substance (1:100 dilution in DCM; Alfa Aesar, Karlsruhe, Germany) and covered by $150 \mu \mathrm{L}$ paraffin oil (Sigma-Aldrich Chemie GmbH, München, Germany) to enable a slow release of the volatile.

Each volatile was checked in two volumes (vial either loaded with $5 \mu \mathrm{L}$ or $10 \mu \mathrm{L}$ ). Each dispenser was fixed with two-sided tape at the lid inside a transparent polypropylene cup (100 mL, Kastelplast $\mathrm{GmbH}$, Mainz-Mombach, Germany) to offer an artificial surface for oviposition. Following [25], the cups were perforated with a needle (60 holes per cup, $\varnothing=1.1 \mathrm{~mm}$ ), so volatiles could evaporate. The two prepared dispenser cups (test substance in DCM and DCM) were placed in the middle of a gauze cage $(60 \times 40 \times 40 \mathrm{~cm}$, The Caterpillar Castle, Live Monarch Foundation, Boca Raton, FL, USA), $20 \mathrm{~cm}$ apart from each other.

Analogous to Rid et al. [34], a grapevine cluster cv. 'Regent' (BBCH 77), containing 10 berries of $V$. vinifera 'Regent', was used as positive control to validate the experimental setup. As negative control, in order to exclude any influence of the solvent or paraffin oil on oviposition of E. ambiguella or L. botrana, the solvent was checked against a cup containing a vial filled exclusively with a cotton wick. Four couples (sexed $<48 \mathrm{~h}$ ) were introduced into one cage to enable adequate egg amounts. Eight repetitive cages were provided for each volatile, volume and species, changing the position of the solvent and the VOC between cages in order to avoid a position effect on egg deposition. The cages were kept in climatic chambers 'Fitotron type SGR233' (Weiss Technik UK Ltd., Loughborough, UK) at 23:19 $\pm 2{ }^{\circ} \mathrm{C}, 70 \pm 10 \%$ relative humidity and a 14:8 h photoperiod with either $1 \mathrm{~h}$ dusk or dawn. Moth species were kept in separated chambers. The experiment was stopped after $72 \mathrm{~h}$ by removing the couples from the cage and counting the eggs deposited outside the cups. After each experiment, the climatic chambers were warmed at $60{ }^{\circ} \mathrm{C}$ for at least $3 \mathrm{~h}$ to enable remained odors to volatilize.

\subsection{Statistical Analyses}

All data were analyzed using the software R—version 3.6.0_'Planting of a Tree' [37]. Statistical differences of the response of the antennae (EAG experiments) by different chemical compounds compared to the respective DCM control were achieved using linear mixed models (LMs) for each species using package 'Ime4' [38] with 'substance' as fixed, 'antenna-ID' as random factor and 'compound-DCM pair' nested in antenna-ID. Post hoc comparisons between the responses were obtained from estimated marginal means (EMM) using function 'emmeans' [39].

For olfactometer assays, the frequency per moth (FPM) and duration (in seconds) per moth (DPM) spent in each volatile sector were recorded in total and during conspicuous behavioral traits (flight-, 
antennae- and/or ovipositor-activity). Statistically significant differences between the four volatile sectors in the arena were calculated using generalized linear models (GLMs) with 'behavior', 'moth species' and 'volatile source' as fixed factors. Statistical models were compared using AICs (Aikaike information criterions) and simplified by removing non-significant factors with the function 'drop1' and F-test. Time measurements and frequencies were transformed by $\log (y+1)$. The experiment was set as valid, if total settlement duration in both air references was not statistically different. In cases of a settlement of specimens in two overlapping sectors, the time and frequency were counted to both sectors. Post hoc comparisons between durations (alternative frequencies) spent by the species in single volatile sectors were generated using EMMs and Tukey's method for $p$-value adjustment. Significance level was set at $p<0.05$.

Relative attractiveness induced by volatiles in the oviposition assay was calculated using the oviposition discrimination index (ODI) mentioned in [40]: ODI $=$ [(number of eggs on cup A (test VOC) - number of eggs on cup B (solvent))/total number of eggs] $\times 100 \%$. The value varies from -100 (negative effect on oviposition) to $+100 \%$ (positive effect on oviposition). Statistical analysis was carried out by applying non-parametric Wilcoxon signed rank test for paired data sets (egg counts).

Box-whisker plots were created using R-package 'ggplot2' [41], whereby lines represent the median, dots the mean, boxes the interquartile range $(\mathrm{IQR})$, whiskers $1.5 \times \mathrm{IQR}$ and dots outside boxes the outliers. Heat maps were plotted using EthoVision ${ }^{\circledR}$ XT (version 10) video tracking software (Noldus Information Technology, Wageningen, The Netherlands).

\section{Results}

\subsection{Perception of VOCs by EAG}

The absolute response $[\mathrm{mV}]$ differed between antennae and between sets of antennae due to their viability and lifetime. For that reason, the antenna ID was used as random factor and the response to the test substance was compared to its respective DCM control. The mean absolute response to ten chemical compounds (10 $\mathrm{gg}$ ) was calculated both for E. ambiguella and L. botrana (Table 1) and compared to the DCM control. All 10 test substances can be perceived by the antenna of both moth species.

Table 1. Average absolute responses of antennae of both E. ambiguella and L. botrana females to ten chemical compounds and to air and solvent control (dichloromethane (DCM)) obtained using EAG experiments.

\begin{tabular}{|c|c|c|c|c|c|c|c|c|}
\hline \multirow{2}{*}{ Compound } & \multicolumn{4}{|c|}{ E. ambiguella } & \multicolumn{4}{|c|}{ L. botrana } \\
\hline & $\mathbf{n}$ & $\begin{array}{c}\text { Response } \\
{[\mathrm{mV}] \pm \mathrm{SD}}\end{array}$ & $p$-Value ${ }^{1}$ & & $\mathbf{n}$ & $\begin{array}{c}\text { Response } \\
{[\mathrm{mV}] \pm \mathrm{SD}}\end{array}$ & $p$-Value ${ }^{1}$ & \\
\hline$(-)$ - $\alpha$-cedrene & $3 \times 5$ & $-0.63 \pm 0.22$ & $2.35 \times 10^{-7}$ & $* * *$ & $3 \times 5$ & $-0.41 \pm 0.18$ & $1.13 \times 10^{-3}$ & $* *$ \\
\hline cumene & $3 \times 5$ & $-0.67 \pm 0.35$ & $1.39 \times 10^{-8}$ & $* * *$ & $3 \times 5$ & $-0.37 \pm 0.10$ & $5.85 \times 10^{-8}$ & $* * *$ \\
\hline$\alpha / \beta$-farnesene & $3 \times 5$ & $-1.45 \pm 0.61$ & $9.94 \times 10^{-7}$ & $* * *$ & $3 \times 5$ & $-1.12 \pm 0.40$ & $7.58 \times 10^{-10}$ & *** \\
\hline (-)-limonene & $3 \times 5$ & $-0.96 \pm 0.35$ & $1.25 \times 10^{-7}$ & $* * *$ & $3 \times 5$ & $-0.82 \pm 0.26$ & $6.47 \times 10^{-8}$ & $* * *$ \\
\hline linalool & $3 \times 5$ & $-1.88 \pm 0.46$ & $8.82 \times 10^{-14}$ & $* * *$ & $3 \times 5$ & $-1.29 \pm 0.41$ & $1.35 \times 10^{-10}$ & $* * *$ \\
\hline (E)/(Z)-linalool oxide (furanoid) & $3 \times 5$ & $-1.40 \pm 0.51$ & $2.77 \times 10^{-11}$ & $* * *$ & $3 \times 5$ & $-0.69 \pm 0.22$ & $1.89 \times 10^{-7}$ & *** \\
\hline$(E) /(Z)$-linalool oxide (pyranoid) & $3 \times 5$ & $-0.98 \pm 0.67$ & $1.68 \times 10^{-5}$ & $* * *$ & $3 \times 5$ & $-0.80 \pm 0.26$ & $1.62 \times 10^{-10}$ & $* * *$ \\
\hline methyl salicylate & $3 \times 5$ & $-1.10 \pm 0.43$ & $1.07 \times 10^{-8}$ & $* * *$ & $3 \times 5$ & $-1.06 \pm 0.46$ & $2.39 \times 10^{-7}$ & $* * *$ \\
\hline DCM & $3 \times 50$ & $-0.44 \pm 0.26$ & & & $3 \times 50$ & $-0.36 \pm 0.18$ & & \\
\hline
\end{tabular}

${ }^{1}$ Statistical differences between the response to the compound and to DCM control by linear mixed model (LM), post hoc estimated marginal mean (EMM) $\left({ }^{* * *} p<0.001 ;{ }^{* *} p<0.01\right)$. 


\subsection{Responsiveness of Moths in the Olfactometer}

\subsubsection{Males}

Pheromones were used to quantify the general attraction of moths within the olfactometer system. Males of E. ambiguella $(\mathrm{n}=22$ of 25$)$ and L. botrana $(\mathrm{n}=23$ of 25$)$ almost entirely entered the olfactometer system within a period of three minutes. During the observation period of five minutes, flight activity was observed in $27.3 \%$ of E. ambiguella and in $60.9 \%$ of L. botrana specimens. The frequency and duration spent by males in each volatile sector was analyzed (Table 2). Due to the frequent flight interruption, the males' antenna activity could not be recorded during the tracking mode.

Table 2. Frequency per moth (FPM) and duration per moth (DPM) spent by males of E. ambiguella (EA) and L. botrana (LB) in the four volatile sectors of the olfactometer system during stay (total observation period of $300 \mathrm{~s}$ ) and flight activity after introducing a pheromone source (pher).

\begin{tabular}{|c|c|c|c|c|c|c|c|c|c|c|}
\hline \multirow{2}{*}{ Species } & \multirow{2}{*}{\multicolumn{2}{|c|}{ Behavior $\mathbf{n}$}} & \multicolumn{4}{|c|}{ FPM in Sector (Mean \pm SE) [n] } & \multicolumn{4}{|c|}{ DPM in Sector (Mean \pm SE) $[s]$} \\
\hline & & & Air & $\begin{array}{c}\text { Reference } \\
1 \text { (Air) }\end{array}$ & Pher & $\begin{array}{c}\text { Reference } \\
2 \text { (Air) }\end{array}$ & Air & $\begin{array}{c}\text { Reference } \\
1 \text { (Air) }\end{array}$ & Pher & $\begin{array}{c}\text { Reference } \\
2 \text { (Air) }\end{array}$ \\
\hline EA & flight & 6 & $5.2 \pm 3.6$ & $9.6 \pm 6.7$ & $7.8 \pm 4.9$ & $10.7 \pm 7.6$ & $2.6 \pm 2.1$ & $8.8 \pm 6.3$ & $18.3 \pm 13.6$ & $7.5 \pm 4.8$ \\
\hline LB & stay & 23 & $30.7 \pm 7.0$ & $29.0 \pm 4.2$ & $31.4 \pm 4.7$ & $37.6 \pm 7.4$ & $75.9 \pm 16.6$ & $\begin{array}{l}113.2 \pm \\
17.0\end{array}$ & $123.8 \pm 16.9$ & $90.2 \pm 16.2$ \\
\hline
\end{tabular}

The moth species had no significant influence on the duration of stay within single sectors (GLM: $\mathrm{F}_{1,254}=0.93 ; p=0.33$ ), hence data of E. ambiguella and L. botrana were merged for further analyses. The duration of males' flight activity in single sectors was short $(4.6 \pm 1.3 \mathrm{~s}, \mathrm{n}=80)$ if compared to the duration of stay in the single sectors of the total recording time $(97.7 \pm 5.3 \mathrm{~s}, \mathrm{n}=180)\left(\mathrm{GLM}\right.$ : $\mathrm{F}_{1,254}=$ 419.82; $p<0.001)$. The volatile sector had a statistically significant influence on the settlement duration of males (GLM: $\mathrm{F}_{3,254}=3.41 ; p=0.016$, Figure 2 ).

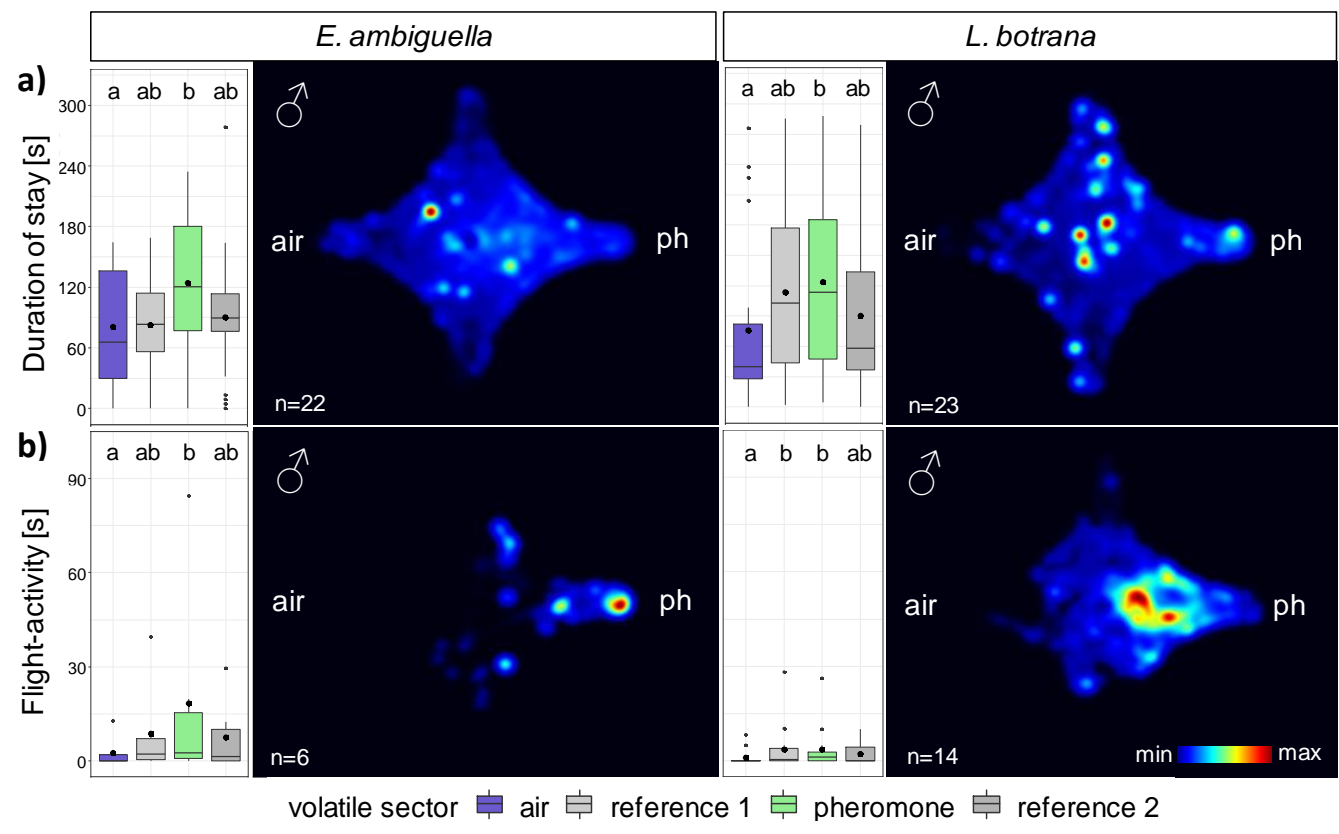

Figure 2. Box-whisker plots and merged heat maps visualizing the duration of (a) stay and (b) flight activity of (left) E. ambiguella and (right) L. botrana males within the four-chamber olfactometer arena after introduction of a pheromone source (ph). Different letters indicate statistical differences between volatile sectors according to generalized linear model (GLM) and post hoc comparisons using estimated marginal means (EMMs) $(p<0.05)$. 
Independent from the observed behavior (stay $(n=45)$ or flight activity $(n=20)$ ), the cumulative time spent by E. ambiguella and L. botrana in the pheromone sector was statistically $\left(\mathrm{z}_{4}=3.14, p<0.01\right)$ longer (stay: $124.0 \pm 11.2 \mathrm{~s}$; flight activity: $8.1 \pm 4.3 \mathrm{~s}$ ) than in the air sector (stay: $78.1 \pm 10.2 \mathrm{~s}$, flight activity: $1.5 \pm 0.8 \mathrm{~s})$.

The moth species influenced the frequency of volatile sector entries (GLM: $\mathrm{F}_{1,254}=13.03 ; p<0.001$ ), with males of E. ambiguella switching more frequently between volatile sectors than males of L. botrana $\left(\mathrm{z}_{2}=3.61, p<0.001\right)$. In contrast, the volatile source had no significant influence on the frequency of entering a volatile sector (GLM: $\left.\mathrm{F}_{3,254}=0.96 ; p=0.41\right)$.

\subsubsection{Females}

The behavior of mated females near volatile compounds emitted by grapevine ( $V$. vinifera 'Regent'; $\mathrm{BBCH}$ 77) served as model for female moths, which are in search of oviposition sites. Activities of the female's antennae were characterized by a pivoting up and down movement of the antennae while standing still. The ovipositor activity was recognizable by palpation of the olfactometer surface with the ovipositor, whereby the abdomen was swinging back and forth. Flight activity of females was rare, so that this behavior was not recorded in our experiments (Table 3).

Table 3. Frequency per moth (FPM) and duration per moth (DPM) spent by females of E. ambiguella (EA) and L. botrana (LB) in the four volatile sectors of the olfactometer system during stay (total observation period of $300 \mathrm{~s}$ ) and specific behaviors (antennae and ovipositor activity) after introducing a grapevine headspace (grape).

\begin{tabular}{|c|c|c|c|c|c|c|c|c|c|}
\hline \multirow{2}{*}{ Species } & \multirow{2}{*}{ Behavior $\mathbf{n}$} & \multicolumn{4}{|c|}{ FPM in Sector (Mean \pm SE) [n] } & \multicolumn{4}{|c|}{ DPM in Sector (Mean \pm SE) $[s]$} \\
\hline & & Air & $\begin{array}{l}\text { Reference } \\
1 \text { (Air) }\end{array}$ & Grape & $\begin{array}{c}\text { Reference } \\
2 \text { (Air) }\end{array}$ & Air & $\begin{array}{c}\text { Reference } \\
1 \text { (Air) }\end{array}$ & Grape & $\begin{array}{c}\text { Reference } \\
2 \text { (Air) }\end{array}$ \\
\hline \multirow{3}{*}{ EA } & stay & $32.8 \pm 9.8$ & $25.3 \pm 9.1$ & $35.5 \pm 10.5$ & $25.8 \pm 7.4$ & $42.7 \pm 19.1$ & $45.5 \pm 19.0$ & $82.3 \pm 25.4$ & $72.6 \pm 22.7$ \\
\hline & antennae 12 & $0.3 \pm 0.3$ & $0.6 \pm 0.3$ & $1.6 \pm 0.5$ & $1.0 \pm 0.4$ & $0.3 \pm 0.3$ & $0.4 \pm 0.2$ & $1.7 \pm 0.8$ & $1.8 \pm 0.9$ \\
\hline & ovipositor 3 & $0.7 \pm 0.3$ & $1.0 \pm 0.6$ & $4.7 \pm 2.9$ & $1.3 \pm 0.9$ & $1.6 \pm 1.2$ & $2.7 \pm 1.5$ & $32.7 \pm 24.1$ & $31.8 \pm 30.6$ \\
\hline \multirow{3}{*}{ LB } & stay & $11.9 \pm 2.5$ & $11.2 \pm 2.4$ & $28.0 \pm 12.1$ & $11.5 \pm 3.0$ & $73.8 \pm 15.4$ & $75.4 \pm 17.6$ & $132.6 \pm 22.1$ & $\begin{array}{c}100.5 \pm \\
21.8\end{array}$ \\
\hline & antennae 17 & $0.7 \pm 0.3$ & $0.6 \pm 0.2$ & $1.4 \pm 0.5$ & $1.1 \pm 0.5$ & $1.9 \pm 0.9$ & $1.5 \pm 0.7$ & $5.3 \pm 2.2$ & $4.6 \pm 2.2$ \\
\hline & ovipositor14 & $2.4 \pm 0.7$ & $3.1 \pm 0.8$ & $3.2 \pm 0.8$ & $2.2 \pm 0.6$ & $12.1 \pm 5.4$ & $27.5 \pm 10.2$ & $27.9 \pm 8.6$ & $21.0 \pm 7.5$ \\
\hline
\end{tabular}

The duration spent by females in a volatile sector of the olfactometer arena (Table 3) was influenced by the factors behavior (GLM: $\left.\mathrm{F}_{1,333}=121.38 ; p<0.001\right)$, moth species (GLM: $\mathrm{F}_{1,333}=8.46 ; p<0.01$ ) and volatile source (GLM: $\left.\mathrm{F}_{3,333}=4.50 ; p<0.01\right)$. Females of E. ambiguella spent significantly less time $(84.6 \pm 1.3 \mathrm{~s})$ within the arena than females of L. botrana $(95.6 \pm 9.0 \mathrm{~s})\left(\mathrm{z}_{2}=-2.91, p<0.001\right)$, which is a consequence of moths moving back to the IIA. Considering the sum of DPM over all four volatile sectors, both species had a significantly shorter duration $\left(\mathrm{z}_{3}=-5.29, p<0.001\right)$ of antennae activity (E. ambiguella: $1.0 \pm 0.3 \mathrm{~s} ;$ L. botrana: $3.3 \pm 0.8 \mathrm{~s}$ ) than ovipositor activity (E. ambiguella: $17.2 \pm 9.5 \mathrm{~s}$; L. botrana: $22.1 \pm 4.0 \mathrm{~s})$.

The duration of stay within single volatile sectors could not be explained by the volatile source, neither for E. ambiguella (GLM: $\mathrm{F}_{3,76}=2.17 ; p=0.10$, Figure 3a left) nor for L. botrana (GLM: $\mathrm{F}_{3,72}=1.64$; $p=0.19$, Figure 3a right). For both moth species, the duration of antennae (Figure $3 b$ ) and ovipositor activity (Figure $3 \mathrm{c}$ ) was triggered by the volatile source. Antennae $\left(\mathrm{z}_{4}=-2.01, p<0.05\right)$ and ovipositor activities $\left(\mathrm{z}_{4}=-3.44, p=0.01\right)$ were statistically shorter in the air sector than in the grapevine sector. 


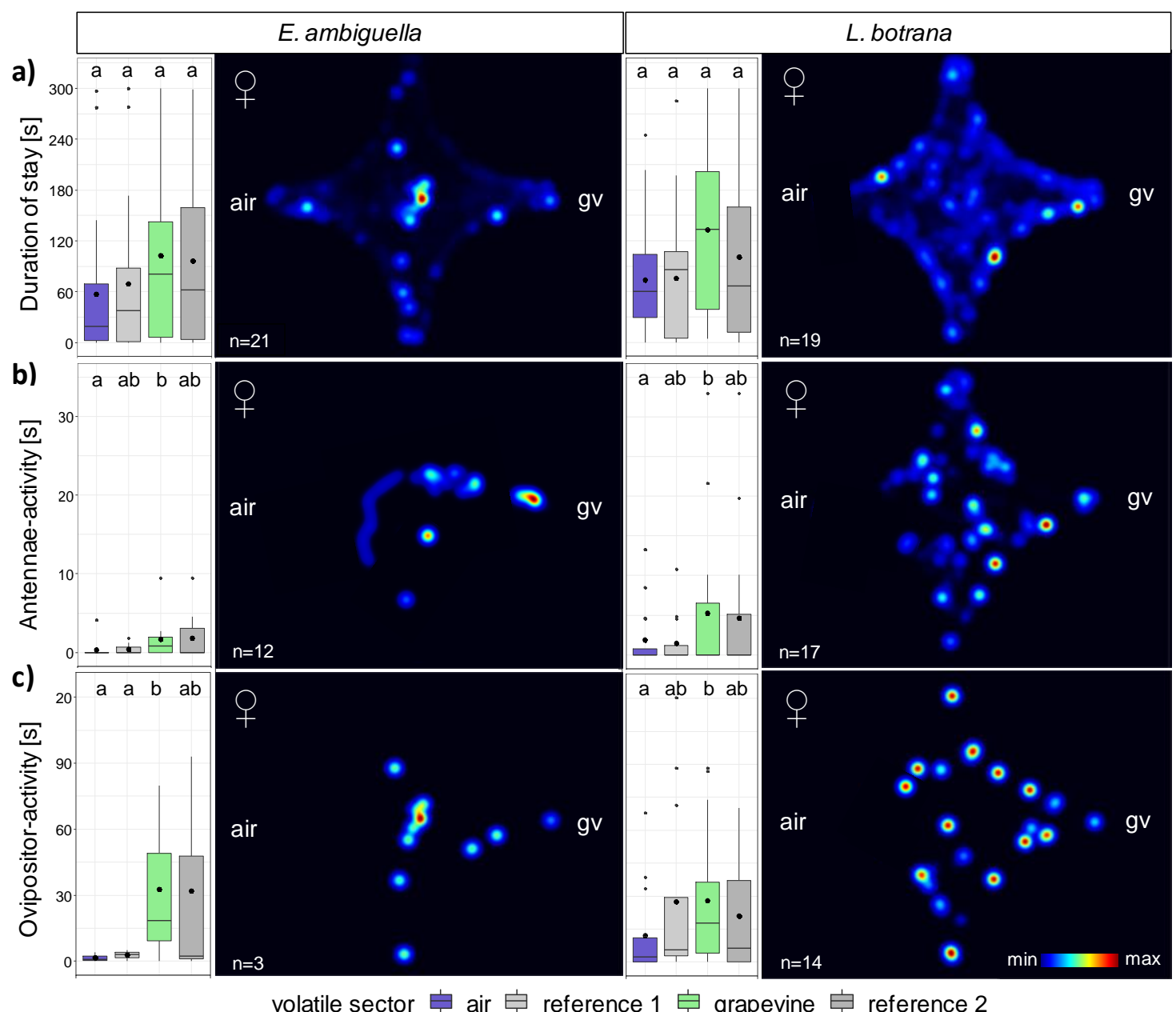

Figure 3. Box-whisker plots and merged heat maps visualizing the duration of (a) stay (b) antennae activity and (c) ovipositor activity of (left) E. ambiguella and (right) L. botrana females within the four-chamber olfactometer arena after introduction of a grapevine headspace (gv). Different letters indicate statistical differences between volatile sectors according to generalized linear model (GLM) and post hoc comparisons using estimated marginal means (EMMs) $(p<0.05)$.

Differences in the frequency of volatile sector entries (Table 3) were a result of the behavior (GLM: $\left.\mathrm{F}_{2,333}=91.30 ; p<0.001\right)$ rather than the insect species $\left(\mathrm{GLM}: \mathrm{F}_{1,333}=0.22 ; p=0.64\right)$ or volatile source $\left(\mathrm{GLM}: \mathrm{F}_{3,333}=1.75 ; p=0.15\right)$.

\subsection{Short-Range Attraction of Females by VOCs}

Due to the fact that females previously did not enter the grapevine sector more frequently than the air sector, we focused in the further studies on the duration spent by the females in the single volatile sectors (full dataset in Table S1).

Although behavior was a factor explaining differences in the duration in all VOCs tested in this study (statistics in Table S2), there were no statistically significant differences between the duration of antennae and ovipositor activity (data not shown). None of the VOCs $(( \pm)$-limonene and $(E) /(Z)$-linalool oxide (pyranoide/furanoide) tested as isomere mixture 1:1) had a statistically significant influence on duration of stay within single volatile sectors during the total observation period (GLM; $p>0.05$; Figure $4 \mathrm{a})$. 


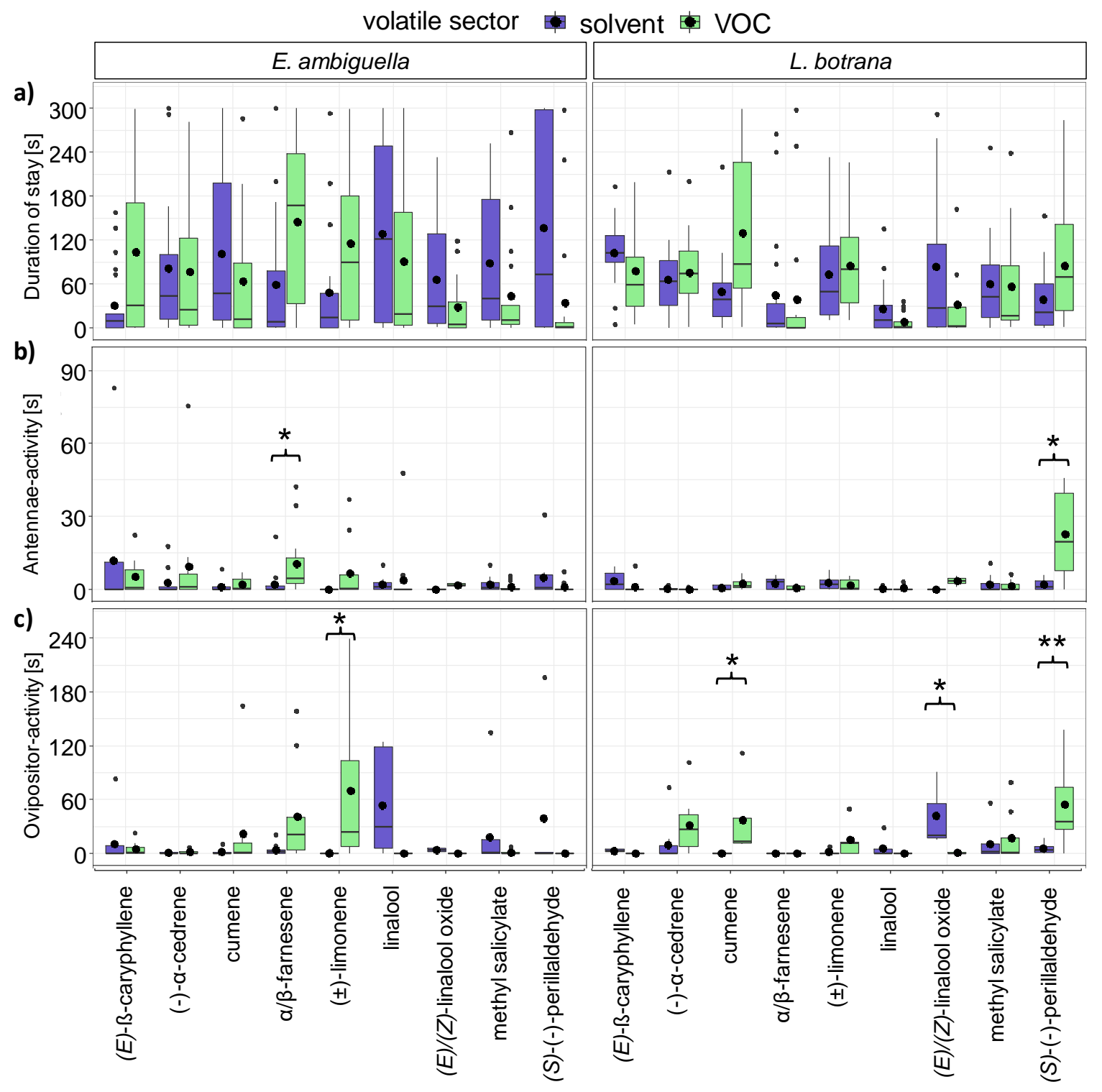

Figure 4. Box-whisker plots visualizing the duration of (a) stay, (b) antennae activity and (c) ovipositor activity of (left) E. ambiguella and (right) L. botrana females within the four-chamber olfactometer arena after introduction of different volatile organic compounds (VOCs). Asterisks indicate statistical differences between VOC and solvent control according to generalized linear model (GLM) and post hoc comparisons using estimated marginal means (EMMs) $\left.{ }^{*} p<0.05 ;{ }^{* *} p<0.01, \mathrm{n}=25\right)$.

The volatiles $\alpha / \beta$-farnesene (mixture of isomers) and ( \pm )-limonene influenced the behavior of E. ambiguella significantly (Table S2). The antennae activity of E. ambiguella was significantly higher $\left(\mathrm{z}_{4}=3.1 ; p<0.05\right.$, Figure $\left.4 \mathrm{~b}\right)$ in the farnesene sector than in the sector of the solvent control. Further, $( \pm$ )-limonene had a positive effect on the ovipositor activity, which was higher in the volatile sector $\left(\mathrm{z}_{4}=2.63 ; p<0.05\right.$, Figure $\left.4 \mathrm{c}\right)$ than in the solvent control.

The behavior of L. botrana was influenced by the compounds cumene, $(E) /(Z)$-linalool oxide (pyranoide/furanoide) and (S)-(-)-perillaldehyde (Table S2). In comparison to the solvent control, the ovipositor activity was significantly higher in the volatile sector of cumene $\left(\mathrm{z}_{4}=2.72 ; p<0.05\right.$, Figure $4 \mathrm{c})$ as well as $(S)-(-)$-perillaldehyde $\left(\mathrm{z}_{4}=3.35 ; p<0.01\right.$, Figure $\left.4 \mathrm{c}\right)$ and significantly lower $\left(\mathrm{z}_{4}=-2.62 ; p<0.05\right.$, Figure $\left.4 \mathrm{c}\right)$ in the volatile sector of $(E) /(Z)$-linalool oxide (pyranoide/furanoide). The compound $(S)-(-)$-perillaldehyde additionally promoted the antennae activity of L. botrana in comparison to DCM significantly $\left(\mathrm{z}_{4}=2.16 ; p<0.05\right.$, Figure $\left.4 \mathrm{~b}\right)$. 


\subsection{Oviposition Induced by VOCs}

The influence of VOCs (1:100 dilutions in DCM) on oviposition behavior of E. ambiguella and L. botrana was dose dependent (Figure 5). None of the compounds tested in our studies attracted E. ambiguella females for oviposition (Figure 5, left) when compared to the solvent control, whereas dispenser systems equipped with $(S)(-)$-perillaldehyde significantly (Wilcoxon signed rank test, $p<0.05$ ) attracted females of L. botrana for oviposition in a volume of $5 \mu \mathrm{L}$ (Figure $5 \mathrm{a}$, right).

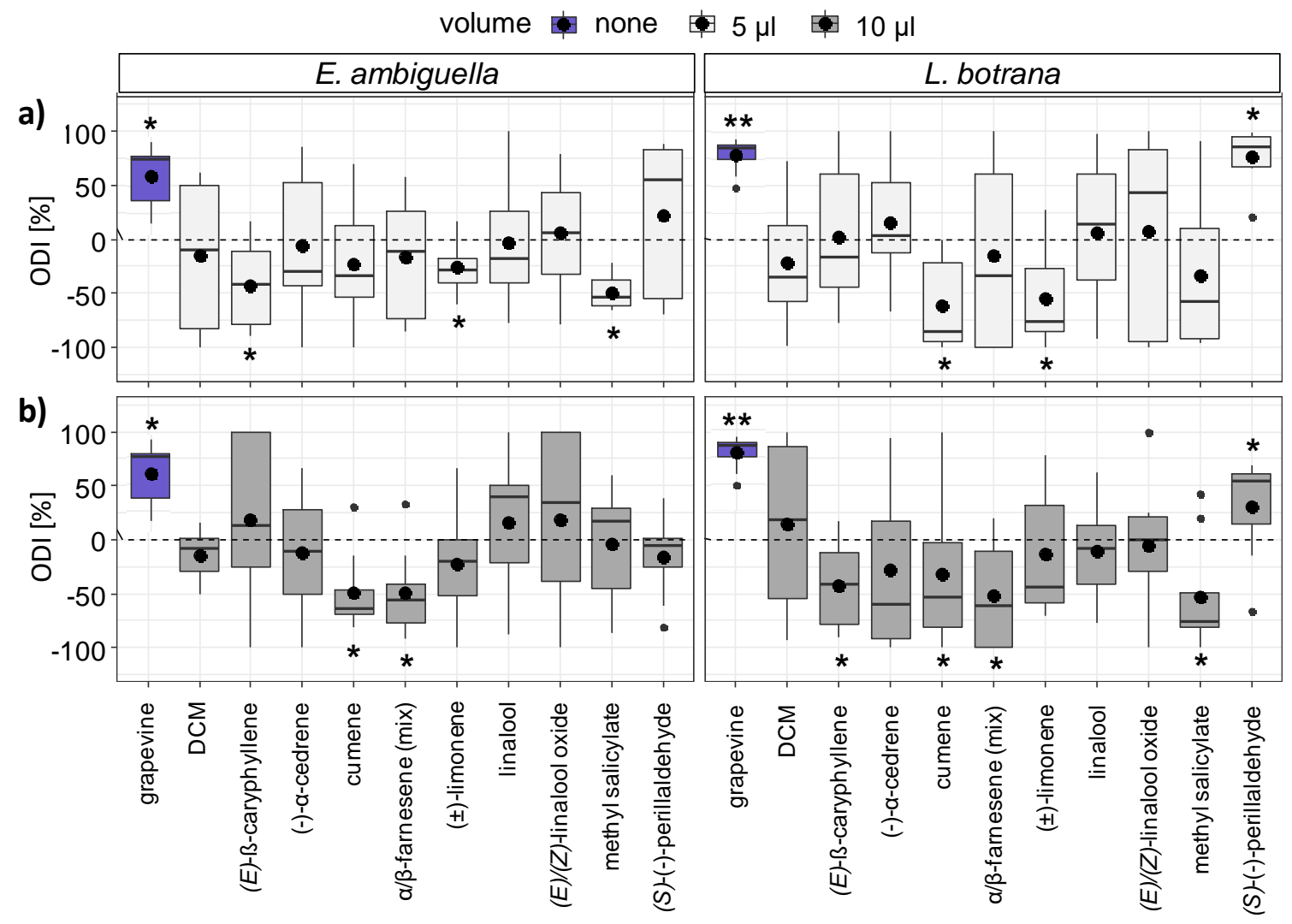

Figure 5. Oviposition preferences of (left) E. ambiguella and (right) L. botrana induced by volatile organic compounds (VOCs) (1:100 dilution in dichloromethane (DCM)) in a volume of (a) $5 \mu \mathrm{L}$ and (b) $10 \mu \mathrm{L}$ (grapevine = positive control, DCM = negative control). Preferences expressed by oviposition discrimination indices (ODI) (negative ODI = repellent; positive ODI $=$ attractant). Asterisks indicate statistical differences between solvent control (DCM) and VOC according to Wilcoxon signed rank test $\left({ }^{*} p<0.05,{ }^{* *} p<0.01 ; \mathrm{n}=8\right)$.

The compounds (E)- $\beta$-caryophyllene, $( \pm)$-limonene and methyl salicylate $(5 \mu \mathrm{L})$ were significant in reducing the egg deposition of E. ambiguella, whereas a comparable effect was observed in the case of cumene and $( \pm)$-limonene $(5 \mu \mathrm{L})$ for L. botrana (Figure $5 \mathrm{a})$.

Increasing the volume to $10 \mu \mathrm{L}$ (Figure $5 \mathrm{~b}$ ) resulted in none of the VOCs tested having a positive effect on oviposition. Dispenser systems were either avoided or no longer discriminable to the solvent. Cups equipped with the compounds cumene and $\alpha / \beta$-farnesene in a volume of $10 \mu \mathrm{L}$ were decreasing the egg deposition of E. ambiguella, whereas $( \pm)$-limonene, $(E)$ - $\beta$-caryophyllene, cumene, $\alpha / \beta$-farnesene and methyl salicylate repelled oviposition of L. botrana.

\section{Discussion}

Grapevine moths do not require the stimulus of a natural plant to accept surfaces for oviposition $[25,32,40]$. L. botrana is essentially nocturnal and mating flight is initiated during night, while oviposition starts with sunset and lasts until night. In contrast, E. ambiguella is flight active 
during dawn and egg laying was observed at noon until night [7,42]. Hence, any visual component in host-seeking behavior, which is known to play a key role in some insects that are active by day [43] is assumed to be less significant, at least for L. botrana [25,32]. Therefore, response to volatile plant odors and fruit surface condition are probably the most likely mechanisms for Lepidoptera species like E. ambiguella and L. botrana for locating suitable host plants for reproduction [21,24,26,27,30,44-46]. Plant odors enhance the attraction to pheromones in many species, having the potential as low-cost attractants in traps $[47,48]$. The synthetic VOCs selected for this study were confirmed to be perceivable by the antennae of E. ambiguella and L. botrana females in EAG experiments and possibly attract female moths for reproduction. Some of them were derived from plants other than grapevine. A single compound, (S)-(-)-perillaldehyde, a volatile emitted by the non-host plant Perilla frutescens [33], was found to promote oviposition of L. botrana. Further VOCs may trigger the female's attraction for reproduction in a similar way.

Oviposition response to VOCs is often assessed over longer periods of time and relies on passive dispenser systems $[25,40,44,49,50]$, which possibly allow a rapid degradation of the chemical compounds [48]. As a consequence, it is difficult to estimate concentration levels, which operate as attractant or repellent for egg deposition.

Hence, this study aimed at developing a four-chamber olfactometer assay to measure the real-time behavioral responses of adult E. ambiguella and L. botrana to VOCs over a short range. Within a four-chamber olfactometer, the air flow builds up sectors of different odor levels, visualized by the distribution of the smoke emitted by the pens. Thus, insects were allowed to select within the arena sectors of preferred odor concentrations, an advantage in comparison to a Y-olfactometer, where moths can only respond to one odor level. Furthermore, it is possible to quantify further behavioral patterns such as sensory probing of the surface by the ovipositor, egg deposition, antennae and flight movements or female calling behavior. This enables the role of the respective substances in the behavior of the grapevine moths to be analyzed.

In the case of males, we observed increased flight activity and duration of stay near the pheromone sector within the olfactometer arena for both species and conclude that the system is suitable to quantify volatile compounds. Based on previous results, which confirmed the attraction of females of $L$. botrana to grape odors in wind tunnels and/or Y-olfactometer experiments [21,24,30,34,51], both species were exposed to the headspace of $V$. vinifera 'Regent'. Independently of moth species, we observed increased ovipositor and antennae activity in the arena's sector which was enriched with grapevine odor. Regarding the duration of stay, the lack of response of females could be a consequence of the plant material tested (e.g., grape variety, amount of plant material and the release rate of plant volatiles) [52] or the lack of required supplementary signals necessary in locating host plants [25]. Possibly, the settlement position of the moth within the arena system, which is known to trigger oviposition [32], has a higher priority in the stimulus cascade relevant for oviposition than olfactory stimuli. The behavior of females, which try to locate suitable egg-laying sites, is reviewed by Galet [53] citing various authors. According to this review, females of both species fly agitatedly between grape clusters and lay eggs on different widespread grapes. We assume that this behavior is reflected by females in the olfactometer system, resulting in duration of stay being evenly distributed over volatile sectors, while orientation to directions (antennae activity) and tasting (ovipositor activity) is influenced by volatiles.

The positive effect of (S)-(-)-perillaldehyde on egg deposition and ovipositor activity could be confirmed for L. botrana in our studies. Ovipositor activity was also higher in the volatile sector than in the solvent control of the compounds $( \pm)$-limonene (E. ambiguella), $(E) /(Z)$-linalool oxide (pyranoide/furanoide) and cumene (L. botrana), whereas none of these compounds operated as attractant for oviposition. This highlights that increased egg deposition is not necessarily a result of increased ovipositor activity. It may rather reflect a gustatory perception of the VOC by the ovipositor receptors as hypothesized by Maher and Thiéry [27]. Cumene, a compound recently identified in the bouquet of grapevine [34], was perceived by the female moth's antennae with lower electrical responses (E. ambiguella: $-0.67 \pm 0.35 \mathrm{mV}$; L. botrana: $-0.37 \pm 0.10 \mathrm{mV})$ when compared to $\alpha / \beta$-farnesene $(E$. 
ambiguella: $-1.45 \pm 0.61 \mathrm{mV}$; L. botrana: $-1.12 \pm 0.40 \mathrm{mV}$ ), while L. botrana females showed increased ovipositor activity within the volatile sector of cumene in the olfactometer system. We may assume a higher detection with organs other than antennae resulting in a behavioral output.

None of the VOCs tested in this study provoked an increased duration of stay within the volatile sector in comparison to the solvent control. This may be a result of the VOC dose or the kind of compound tested. In the olfactometer experiments, the dose was adjusted to the same as in our EAG experiments $(10 \mu \mathrm{g} / \mu \mathrm{L})$, which conforms to other studies with grapevine moths [21,22,24]. Deviating VOC doses may result in changes of the behavioral response of females as observed for L. botrana in Y-olfactometer experiments [54] or oviposition tests in this study.

Furthermore, moth species such as L. botrana possibly avoid artificial and natural oviposition sites treated with particular VOCs as, e.g., shown by Thiéry et al. [55] for the substance methanol or Silva et al. [54] for essential oils of the non-host plant Schinus molle L. In this study, some compounds (methyl salicylate, $\alpha / \beta$-farnesene and (E)- $\beta$-caryophyllene) had a negative effect on egg deposition while presenting no increased ovipositor activity in comparison to solvent. These compounds are probably to a greater extent perceived by antennae rather than other extremities of females as suggested by Maher and Thiéry [27].

The compound methyl salicylate, derived from salicylic acid, is released in larger amounts by many plants after damage, infection or abiotic stress [56-59]. In some cases, this VOC acts as plant chemical defense to attract natural enemies [59-61]. However, such plants may be less preferred by gravid females for oviposition due to the lack of berry persistence and/or the nutritional conditions necessary for offspring development. For instance, the odor of Botrytis cinerea-inoculated fruits reduced oviposition of L. botrana [62]. This may explain the repellent effect on oviposition in this study. Furthermore, Ulland et al. [63] found this compound to reduce the oviposition in the cabbage moth Mamestra brassicae.

The isomer mixture of $\alpha / \beta$-farnesene had no influence on the attraction of both species. This may be a result of the dose and/or the kind of isomere mixture tested. It may contain sesquiterpenes, $(E)$ - $\beta$-farnesene, $(Z, Z)$ - $\alpha$-farnesene, $(Z, E)$ - $\alpha$-farnesene and bisabolene. Two of the four stereoisomers of $\alpha$-farnesene, $(E, E)$ - $\alpha$-farnesene and $(Z, E)$ - $\alpha$-farnesene, attracted larvae of the codling moth $C$. pomonella, while $(E)$ - and $(Z)$-isomers of $\beta$-farnesene had no effect on larvae under controlled conditions [64-66]. The isomer $(E, E)$ - $\alpha$-farnesene was additionally found to promote oviposition of C. pomonella [67]. Furthermore, $C$. pomonella responded with walking in Y-olfactometer assays at a higher rate to 0.01 $\mu \mathrm{g}$ of a $(E, E)$ - and $(Z, E)$ - $\alpha$-farnesene isomer mixture than to other doses tested $(0.001,0.1,1,10 \mu \mathrm{g})$ and solvent control [68]. Ongoing studies should therefore rely on testing a variety of VOC doses and all isomers.

Future studies aim to decode essential VOCs affecting host plant acceptance for reproduction of grapevine moths. The method developed in this study could be used to validate the suitability of VOCs for short-range attraction and measure behavioral patterns related to oviposition. This will finally support the development of a so-called 'm-ovi-card', a specific egg-monitoring tool, which aims at reflecting critical threshold levels of pest infestations in vineyards to prohibit immoderate insecticide applications [26,32,34]. Therefore, a combination of attractive VOCs and an artificial surface that fulfills the visual and tactile requirements necessary for grape moth females to accept surfaces for oviposition is still under investigation.

\section{Conclusions}

This study indicates that the short-range attraction of female grapevine moths E. ambiguella and L. botrana can be triggered by VOCs. We assume that VOCs emitted by grapevine are essential for short-range orientation due to the fact that the female's antennae activity was longer in the grapevine than in the air sector. The four-chamber olfactometer system enables important behavioral patterns to be tracked, like ovipositor activity, which are often disregarded in the evaluation of physical and chemical stimuli for oviposition. Increased durations of ovipositor activities suggest that females 
have the ability to recognize specific VOCs by the ovipositor, which could attract or repel females for egg deposition.

Supplementary Materials: The following are available online at http://www.mdpi.com/2075-4450/11/1/45/s1, Table S1: Frequency (FPM) and duration (DPM) spent by E. ambiguella and L. botrana females in each of the four volatile sectors of the olfactometer system during specific behaviors (stay, antenna and/or ovipositor activity) after introducing a volatile organic compound (VOC) and a solvent (DCM) source in opposite sectors, Table S2: Summary of statistical parameters explaining the duration spent by E. ambiguella or L. botrana within the olfactometer arena.

Author Contributions: Conceptualization, A.M., M.R., J.G. and C.H.; data curation, A.M. and S.B.; formal analysis, A.M. and M.R.; funding acquisition, J.G. and C.H.; investigation, A.M.; methodology, A.M., M.R. and S.B.; project administration, J.G. and C.H.; software, A.M.; visualization, A.M.; writing—original draft, A.M.; writing-review and editing, M.R., J.G. and C.H. All authors have read and agreed to the published version of the manuscript.

Funding: This research was funded by the Federal Ministry of Food and Agriculture (BMEL) based on a decision of the Parliament of the Federal Republic of Germany via the Federal Office for Agriculture and Food (BLE) under the innovation support program number 2814701611.

Acknowledgments: The authors would like to thank David Markheiser for creating the image of the olfactometer system as well as Anita Kramm and Thomas Gramm (JKI, Siebeldingen) for raising experimental plants.

Conflicts of Interest: The authors declare no conflict of interest.

\section{Appendix A}

Table A1. Evaluated volatile organic compounds selected from synthetic volatile blends attracting females of L. botrana in wind tunnel studies [28-30] and/or identification from grapevine headspace [34].

\begin{tabular}{|c|c|c|c|c|c|c|}
\hline \multirow{2}{*}{ Compound } & \multicolumn{2}{|c|}{ Tasin et al., 2007} & \multirow{2}{*}{$\begin{array}{c}\text { Anfora et al., } 2009 \\
\text { PS } 33^{*}\end{array}$} & \multicolumn{2}{|c|}{ Tasin et al., 2010} & \multirow{2}{*}{$\begin{array}{c}\text { Rid et al., } 2019 \\
\text { Grapevine * }\end{array}$} \\
\hline & $\mathrm{L}^{*}$ & B * & & GM * & $\mathrm{DM}^{*}$ & \\
\hline \multicolumn{7}{|l|}{ Monoterpenes } \\
\hline $\begin{array}{l}(E) /(Z) \text {-linalool oxide } \\
\text { (furanoid) }\end{array}$ & O & $\bullet$ & 0 & $\bullet$ & $\bullet$ & $\bullet$ \\
\hline $\begin{array}{l}(E) /(Z) \text {-linalool oxide } \\
\text { (pyranoid) }\end{array}$ & O & 0 & 0 & $\bigcirc$ & $\bullet$ & O \\
\hline$( \pm)$-limonene & 0 & $\bigcirc$ & $\bullet$ & $\bigcirc$ & 0 & $\bullet$ \\
\hline linalool & 0 & $\bullet$ & $\bullet$ & $\bullet$ & $\bullet$ & $\bullet$ \\
\hline \multicolumn{7}{|l|}{ Sesquiterpenes } \\
\hline (E)- $\beta$-caryophyllene & • & $\bullet$ & - & $\bullet$ & $\bullet$ & $\bullet$ \\
\hline (E)- $\beta$-farnesene & • & 0 & 0 & $\bullet$ & $\bigcirc$ & $\bullet$ \\
\hline$(E, E)$ - $\alpha$-farnesene & 0 & $\bullet$ & • & $\bullet$ & $\bullet$ & $\bullet$ \\
\hline$(-)$ - $\alpha$-cedrene & 0 & ○ & 0 & 0 & 0 & $\bullet$ \\
\hline \multicolumn{7}{|l|}{ Benzenoids } \\
\hline methyl salicylate & 0 & $\bullet$ & $\bullet$ & $\bullet$ & $\bullet$ & $\bullet$ \\
\hline cumene & 0 & 0 & 0 & 0 & 0 & - \\
\hline
\end{tabular}

- Compound present; $\bigcirc$ Compound absent. * Name of the volatile mixture used in the literature cited.

\section{References}

1. Knolhoff, L.M.; Heckel, D.G. Behavioral Assays for Studies of Host Plant Choice and Adaptation in Herbivorous Insects. Annu. Rev. Entomol. 2014, 59, 263-278. [CrossRef]

2. Pavan, F.; Stefanelli, G.; Villani, A.; Cargnus, E. Influence of Grapevine Cultivar on the Second Generations of Lobesia botrana and Eupoecilia ambiguella. Insects 2018, 9, 8. [CrossRef] [PubMed]

3. Gilligan, T.M.; Epstein, M.E.; Passoa, S.C.; Powell, J.A.; Sage, O.C.; Brown, J.W. Discovery of Lobesia Botrana ([Denis \& Schiffermuller]) in California: An Invasive Species New to North America (Lepidoptera: Tortricidae). Proc. Entomol. Soc. Wash. 2011, 113, 14-30. [CrossRef]

4. Varela, L.G.; Smith, R.J.; Cooper, M.; Hoenisch, R.W. European grapevine moth, Lobesia botrana, in Napa Valley vineyards. Pract. Winery Vineyard 2010, 2010, 1-5.

5. Gonzalez, M. Lobesia botrana: Polilla da la uva. Rev. Enol. 2010, 2, 2-5. 
6. Lucchi, A.; Sambado, P.; Royo, A.B.J.; Bagnoli, B.; Benelli, G. Lobesia botrana males mainly fly at dusk: Video camera-assisted pheromone traps and implications for mating disruption. J. Pest Sci. 2018, 91, 1327-1334. [CrossRef]

7. Stellwaag, F. Neue Foschungen über Mottenflug, Eiablage und Eidauer der Traubenwickler. Der Dtsch. Weinbau 1943, 22, 203-206.

8. Balachowsky, A.; Mensil, L. Les insectes nuisibles aux plantes cultivées. Paris 1935, 1, 137.

9. Savopoulou-Soultani, M.; Stavridis, D.G.; Tzanakakis, M.E. Development and reproduction of Lobesia botrana on vine and olive inflorescences. Entomol. Hell. 2017, 8, 29-35. [CrossRef]

10. Thiery, D.; Moreau, J. Relative performance of European grapevine moth (Lobesia botrana) on grapes and other hosts. Oecologia 2005, 143, 548-557. [CrossRef]

11. Roditakis, N.E. Effectiveness of Bacillus thuringiensis Berliner var. Kurstaki on the Grape Berry Moth Lobesia botrana Den. and Shiff. (Lepidoptera, Tortricidae) under Field and Laboratory Conditions in Crete. Entomol. Hell. 1986, 4, 31-35. [CrossRef]

12. Stellwaag, F. Die Weinbauinsekten Der Kulturländer; Paul Parey: Berlin, Germany, 1928.

13. Broumas, T.; Stavraki, H.; Souliotis, C.; Sarafis, N. Observations on the Biology of Grape Moth Lobesia Botrana De. et. Schiff in Kavala, Greece; A.A. In Proceedings of the Meeting of the EC Expert's Group, Thessaloniki, Greece, 6-8 October 1987; Balkema: Roterdam, The Netherlands, 1989; pp. 57-62.

14. Moschos, T. Yield loss quantification and assessment of economic injury level for the anthophagous generation of the European grapevine moth Lobesia botrana Den. et Schiff. (Lepidoptera: Tortricidae). Int. J. Pest Manag. 2005, 51, 81-89. [CrossRef]

15. Delbac, L.; Thiery, D. Damage to grape flowers and berries by Lobesia botrana larvae (Denis \& Schiffernuller) (Lepidoptera: Tortricidae), and relation to larval age. Aust. J. Grape Wine Res. 2016, 22, 256-261. [CrossRef]

16. Fermaud, M.; Lemenn, R. Association of Botrytis cinerea with Grape Berry Moth Larvae. Phytopathology 1989, 79, 651-656. [CrossRef]

17. Roehrich, R.; Carles, J.P.; Tresor, C.; Devathaire, M.A. Experiments of Pheromonal Control on the Grape Vine Moths Lobesia botrana and Eupoecilia ambiguella. Ann. Zool. Ecol. Anim. 1979, 11, 659-675.

18. Ioriatti, C.; Guzzon, R.; Anfora, G.; Ghidoni, F.; Mazzoni, V.; Villegas, T.R.; Dalton, D.T.; Walton, V.M. Drosophila suzukii (Diptera: Drosophilidae) Contributes to the Development of Sour Rot in Grape. J. Econ. Entomol. 2018, 111, 283-292. [CrossRef]

19. Barata, A.; Santos, S.C.; Malfeito-Ferreira, M.; Loureiro, V. New Insights into the Ecological Interaction Between Grape Berry Microorganisms and Drosophila Flies During the Development of Sour Rot. Microb. Ecol. 2012, 64, 416-430. [CrossRef]

20. Schmidt-Busser, D.; von Arx, M.; Connetable, S.; Guerin, P.M. Identification of host-plant chemical stimuli for the European grape berry moth Eupoecilia ambiguella. Physiol. Entomol. 2011, 36, 101-110. [CrossRef]

21. Tasin, M.; Anfora, G.; Ioriatti, C.; Carlin, S.; De Cristofaro, A.; Schmidt, S.; Bengtsson, M.; Versini, G.; Witzgall, P. Antennal and behavioral responses of grapevine moth Lobesia botrana females to volatiles from grapevine. J. Chem. Ecol. 2005, 31, 77-87. [CrossRef]

22. von Arx, M.; Schmidt-Busser, D.; Guerin, P.M. Host plant volatiles induce oriented flight behaviour in male European grapevine moths, Lobesia botrana. J. Insect Physiol. 2011, 57, 1323-1331. [CrossRef]

23. Vacas, S.; Alfaro, C.; Zarzo, M.; Navarro-Llopis, V.; Primo, J. Effect of sex pheromone emission on the attraction of Lobesia botrana. Entomol. Exp. Appl. 2011, 139, 250-257. [CrossRef]

24. Tasin, M.; Backman, A.C.; Bengtsson, M.; Varela, N.; Ioriatti, C.; Witzgall, P. Wind tunnel attraction of grapevine moth females, Lobesia botrana, to natural and artificial grape odour. Chemoecology 2006, 16, 87-92. [CrossRef]

25. Tasin, M.; Lucchi, A.; Ioriatti, C.; Mraihi, M.; De Cristofaro, A.; Boger, Z.; Anfora, G. Oviposition Response of the Moth Lobesia botrana to Sensory Cues from a Host Plant. Chem. Senses 2011, 36, 633-639. [CrossRef] [PubMed]

26. Rid, M.; Markheiser, A.; Hoffmann, C.; Gross, J. Waxy bloom on grape berry surface is one important factor for oviposition of European grapevine moths. J. Pest Sci. 2018, 91, 1225-1239. [CrossRef]

27. Maher, N.; Thiery, D. Distribution of chemo- and mechanoreceptors on the tarsi and ovipositor of female European grapevine moth, Lobesia botrana. Entomol. Exp. Appl. 2004, 110, 135-143. [CrossRef]

28. Tasin, M.; Backman, A.C.; Coracini, M.; Casado, D.; Ioriatti, C.; Witzgall, P. Synergism and redundancy in a plant volatile blend attracting grapevine moth females. Phytochemistry 2007, 68, 203-209. [CrossRef] 
29. Tasin, M.; Backman, A.C.; Anfora, G.; Carlin, S.; Ioriatti, C.; Witzgall, P. Attraction of Female Grapevine Moth to Common and Specific Olfactory Cues from 2 Host Plants. Chem. Senses 2010, 35, 57-64. [CrossRef]

30. Anfora, G.; Tasin, M.; De Cristofaro, A.; Ioriatti, C.; Lucchi, A. Synthetic Grape Volatiles Attract Mated Lobesia botrana Females in Laboratory and Field Bioassays. J. Chem. Ecol. 2009, 35, 1054-1062. [CrossRef]

31. Thiery, D.; Gabel, B. Inter-Specific Avoidance of Egg-Associated Semiochemicals in 4 Tortricids. Experientia 1993, 49, 998-1001. [CrossRef]

32. Markheiser, A.; Rid, M.; Biancu, S.; Gross, J.; Hoffmann, C. Physical factors influencing the oviposition behaviour of European grapevine moths Lobesia botrana and Eupoecilia ambiguella. J. Appl. Entomol. 2018, 142, 201-210. [CrossRef]

33. Cattaneo, A.M.; Bengtsson, J.M.; Borgonovo, G.; Bassoli, A.; Anfora, G. Response of the European grapevine moth Lobesia botrana to somatosensory-active volatiles emitted by the non-host plant Perilla frutescens. Physiol. Entomol. 2014, 39, 229-236. [CrossRef]

34. Rid, M.; Markheiser, A.; Stein, S.; Hoffmann, C.; Gross, J. Volatiles of several grapevine cultivars emitted at different phenological stages linked to discriminatory ability of grapevine moths. J. Plant Dis. Protect. 2019, 126, 115-127. [CrossRef]

35. Cattaneo, A.M.C. Response of the tortricid pest Lobesia botrana to volatiles emitted by the non-host plant Perilla frutescens. Chem. Senses 2014, 39, 91.

36. Rid, M.; Mesca, C.; Ayasse, M.; Gross, J. Apple Proliferation Phytoplasma Influences the Pattern of Plant Volatiles Emitted Depending on Pathogen Virulence. Front. Ecol. Evol. 2016, 3, 152. [CrossRef]

37. RCoreTeam. R: A Language and Environment for Staistical Computing. Available online: https://www.Rproject.org (accessed on 15 September 2019).

38. Bates, D.; Machler, M.; Bolker, B.M.; Walker, S.C. Fitting Linear Mixed-Effects Models Using lme4. J. Stat. Softw. 2015, 67, 1-48. [CrossRef]

39. Lenth, R. Emmeans: Estimated Marginal Means, AKA Least-Squares Means. R Package Version 1.3.4. Available online: https://CRAN.R-project.org/package=emmeans (accessed on 15 September 2019).

40. Maher, N.; Thiery, D. A bioassay to evaluate the activity of chemical stimuli from grape berries on the oviposition of Lobesia botrana (Lepidoptera: Tortricidae). Bull. Entomol. Res. 2004, 94, 27-33. [CrossRef]

41. Wickham, H. Ggplot2: Elegant Graphics for Data Analysis. Available online: https://ggplot2.tidyverse.org (accessed on 15 September 2019).

42. Götz, B. Neue Apparate zum Studium der Insektenphysiologie. Sonderdr. Die Umschau 1941, 49, 779-781.

43. Prokopy, R.J.; Owens, E.D. Visual Detection of Plants by Herbivorous Insects. Annu. Rev. Entomol. 1983, 28, 337-364. [CrossRef]

44. Gabel, B.; Thiery, D. Oviposition response of Lobesia botrana females to long-chain free fatty acids and esters from its eggs. J. Chem. Ecol. 1996, 22, 161-171. [CrossRef]

45. Gabel, B.; Thiery, D.; Suchy, V.; Marionpoll, F.; Hradsky, P.; Farkas, P. Floral Volatiles of Tanacetum vulgare L Attractive to Lobesia botrana Den-Et-Schiff Females. J. Chem. Ecol. 1992, 18, 693-701. [CrossRef]

46. Schoonhoven, L.M. Insect-plant relationships: The whole is more than the sum of its parts. Entomol. Exp. Appl. 2005, 115, 5-6. [CrossRef]

47. Likhayo, P.W.; Hodges, R.J. Field monitoring Sitophilus zeamais and Sitophilus oryzae (Coleoptera: Curculionidae) using refuge and flight traps baited with synthetic pheromone and cracked wheat. J. Stored Prod. Res. 2000, 36, 341-353. [CrossRef]

48. Nielsen, M.C.; Sansom, C.E.; Larsen, L.; Worner, S.P.; Rostas, M.; Chapman, R.B.; Butler, R.C.; de Kogel, W.J.; Davidson, M.M.; Perry, N.B.; et al. Volatile compounds as insect lures: Factors affecting release from passive dispenser systems. N. Zeal. J. Crop Hort. Sci. 2019, 47, 208-223. [CrossRef]

49. Moreau, J.; Rahme, J.; Benrey, B.; Thiery, D. Larval host plant origin modifies the adult oviposition preference of the female European grapevine moth Lobesia botrana. Naturwissenschaften 2008, 95, 317-324. [CrossRef]

50. Birgucu, A.K.; Turanli, F.; Gumus, E.; Guzel, B.; Karsavuran, Y. The effect of grape cultivars on oviposition preference and larval survival of Lobesia botrana Den. \& Schiff. (Lepidoptera: Tortricidae). Fresen. Environ. Bull. 2015, 24, 33-38.

51. Hurtrel, B.; Thiery, D. Modulation of flight activity in Lobesia botrana Den. \& Schiff. (Lepidoptera: Tortricidae) females studied in a wind tunnel. J. Insect Behav. 1999, 12, 199-211. [CrossRef]

52. von Arx, M.; Schmidt-Busser, D.; Guerin, P.M. Plant Volatiles Enhance Behavioral Responses of Grapevine Moth Males, Lobesia botrana to Sex Pheromone. J. Chem. Ecol. 2012, 38, 222-225. [CrossRef] 
53. Galet, P. Les Maladies Et Les Parasites De La Vigne; Galet, P., Ed.; Impr. du Paysan du Midi: Montpellier, France, 1982.

54. Silva, D.; Curkovic, T.; Ceballos, R. Behavioral and antennal responses of Lobesia botrana (Lepidoptera: Tortricidae) to volatiles from the non-host plant Schinus molle L. (Anacardiaceae). Chil. J. Agric. Res. 2019, 79, 165-171. [CrossRef]

55. Thiery, D.; Gabel, B.; Farkas, P.; Pronier, V. Identification of an Oviposition-Regulating Pheromone in the European Grapevine Moth, Lobesia botrana (Lepidoptera, Tortricidae). Experientia 1992, 48, 697-699. [CrossRef]

56. Hatanaka, A.; Kajiwara, T.; Kenji, M. The biogeneration of green odor by green leaves and it's physiological functions-Present, past and future. Z. Für Nat. C 1995, 50, 467-472. [CrossRef]

57. Lin, Y.W.; Qasim, M.; Hussain, M.; Akutse, K.S.; Avery, P.B.; Dash, C.K.; Wang, L.D. The Herbivore-Induced Plant Volatiles Methyl Salicylate and Menthol Positively affect Growth and Pathogenicity of Entomopathogenic Fungi. Sci. Rep. 2017, 7. [CrossRef] [PubMed]

58. Marques, A.M.; Lima, M.C.H.P.; Araujo, H.C.; Esteves, R.L.; Kaplan, M.A.C. Evaluation of the volatile components and the seasonal variation of the methyl salicylate from Stifftia chrysantha Mikan by HS-SPME/GC-MS. Bol. Lat. Caribe Plantas Med. Aromat. 2012, 11, 413-419.

59. James, D.G. Field evaluation of herbivore-induced plant volatiles as attractants for beneficial insects: Methyl salicylate and the green lacewing, Chrysopa nigricornis. J. Chem. Ecol. 2003, 29, 1601-1609. [CrossRef] [PubMed]

60. Snoeren, T.A.L.; Mumm, R.; Poelman, E.H.; Yang, Y.; Pichersky, E.; Dicke, M. The Herbivore-Induced Plant Volatile Methyl Salicylate Negatively Affects Attraction of the Parasitoid Diadegma semiclausum. J. Chem. Ecol. 2010, 36, 479-489. [CrossRef] [PubMed]

61. Zhu, J.W.; Park, K.C. Methyl salicylate, a soybean aphid-induced plant volatile attractive to the predator Coccinella septempunctata. J. Chem. Ecol. 2005, 31, 1733-1746. [CrossRef]

62. Tasin, M.; Betta, E.; Carlin, S.; Gasperi, F.; Mattivi, F.; Pertot, I. Volatiles that encode host-plant quality in the grapevine moth. Phytochemistry 2011, 72, 1999-2005. [CrossRef]

63. Ulland, S.; Ian, E.; Mozuraitis, R.; Borg-Karlson, A.K.; Meadow, R.; Mustaparta, H. Methyl salicylate, identified as primary odorant of a specific receptor neuron type, inhibits oviposition by the moth Mamestra brassicae L. (Lepidoptera, noctuidae). Chem. Senses 2008, 33, 35-46. [CrossRef]

64. Sutherland, O.R.; Hutchins, R.F. Attraction of Newly Hatched Codling Moth Larvae (Laspeyresia pomonella) to Synthetic Stereo-Isomers of Farnesene. J. Insect Physiol. 1973, 19, 723-727. [CrossRef]

65. Sutherland, O.R.; Hutchins, R.F. Alpha-Farnesene, a Natural Attractant for Codling Moth Larvae. Nature 1972, 239, 170. [CrossRef]

66. Hern, A.; Dorn, S. Sexual dimorphism in the olfactory orientation of adult Cydia pomonella in response to alpha-farnesene. Entomol. Exp. Appl. 1999, 92, 63-72. [CrossRef]

67. Wearing, C.H.; Hutchins, R.F. Alpha-Farnesene, a Naturally Occurring Oviposition Stimulant for Codling Moth, Laspeyresia pomonella. J. Insect Physiol. 1973, 19, 1251-1256. [CrossRef]

68. Yan, F.; Bengtsson, M.; Makranczy, G.; Lofqvist, J. Roles of alpha-farnesene in the behaviors of codling moth females. Z. Naturforsch. C 2003, 58, 113-118. [CrossRef] [PubMed]

(C) 2020 by the authors. Licensee MDPI, Basel, Switzerland. This article is an open access article distributed under the terms and conditions of the Creative Commons Attribution (CC BY) license (http://creativecommons.org/licenses/by/4.0/). 